\title{
Salmonella and cancer: from pathogens to therapeutics*
}

\author{
Paulina Chorobik, Dominik Czaplicki, Karolina Ossysek and Joanna Bereta ${ }^{\bowtie}$ \\ Department of Cell Biochemistry, Faculty of Biochemistry, Biophysics and Biotechnology, Jagiellonian University in Kraków, Kraków, Poland
}

Bacterial cancer therapy is a concept more than 100 years old - yet, all things considered, it is still in early development. While the use of many passive therapeutics is hindered by the complexity of tumor biology, bacteria offer unique features that can overcome these limitations. Microbial metabolism, motility and sensitivity can lead to site-specific treatment, highly focused on the tumor and safe to other tissues. Activation of tumor-specific immunity is another important mechanism of such therapies. Several bacterial strains have been evaluated as cancer therapeutics so far, Salmonella Typhimurium being one of the most promising. S. Typhimurium and its derivatives have been used both as direct tumoricidal agents and as cancer vaccine vectors. VNP20009, an attenuated mutant of $S$. Typhimurium, shows significant native toxicity against murine tumors and was studied in a first-in-man phase I clinical trial for toxicity and anticancer activity. While proved to be safe in cancer patients, insufficient tumor colonization of VNP20009 was identified as a major limitation for further clinical development. Antibody-fragment-based targeting of cancer cells is one of the few approaches proposed to overcome this drawback.

Key words: bacterial cancer therapy, immunotherapy, cancer vaccine, tumor targeting, Salmonella, VNP20009

Received: 01 May, 2013; accepted: 26 June, 2013; available on-line: 05 July, 2013

\section{INTRODUCTION}

It was at the end of the $19^{\text {th }}$ century that bacteria were for the first time intentionally applied for cancer treatment. William Coley, a bone sarcoma surgeon at the Memorial Hospital in New York, having conducted a thorough literature search, found 47 well-documented cases of beneficial influence of serious bacterial infections in tumor patients (McCarthy, 2006). On the basis of the then-available data he concocted a mixture of killed Streptococcus pyogenes and Serratia marcescens bacteria, which became known as Coley's toxin. Over the next forty years Coley applied his toxin to almost 1000 patients who suffered from various types of inoperable cancers. Striving to improve the effectiveness of the therapy, he used various doses of his toxin, different regimens and durations of treatment, as well as different routes of application and therefore it is difficult to fully comprehend his enormous work. In many cases several-month treatment resulted in complete tumor regression. The fiveyear survival period for patients suffering from inoperable carcinomas ranged from 34 to $73 \%$, and for those suffering from inoperable sarcomas was in the range between 13 and $79 \%$, varying with the tumor subtype (Green \& Hoption Cann, 2007). However, the results of
Coley's treatment have been non-reproducible, uncertain, and unpredictable and therefore his therapy often met with strong criticism from the medical community. At the beginning of the $20^{\text {th }}$ century it was gradually displaced by newly developing radiotherapy, which resulted in fast tumor destruction and pain relief, although not necessarily in complete tumor eradication, especially at the stage of advanced, metastatic disease.

With the progress of immunology it became clear that the mechanism of action of Coley's toxin involves activation of the immune system and a multilevel modulation of immune response. This understanding restored interest in possible therapeutic applicability of Coley's approach. Richardson and coworkers (1999) compared the effectiveness of Coley's toxin with contemporary cancer therapies based on published results concerning patients treated with Coley's toxin and matched controls from National Cancer Institute's Surveillance Epidemiology End Result database (Richardson et al., 1999). They found higher rates of ten-year survival of Coley's patients compared to patients subjected to modern treatment in kidney cancer (33 vs. 23\%), ovarian cancer (55 vs. $29 \%$ ), and sarcoma (50 vs. 38\%), which gives food for thought. The attempts to re-evaluate Coley's concept are undertaken anew. In 2012 the new phase 1 clinical trial investigating the safety and the dosage of biochemically well-defined and good manufacturing practice (GMP)compliant Coley's toxin, presently known as MBV (mixed bacterial vaccine) was started in the Ludwig Institute for Cancer Research. It involves patients suffering from cancers expressing NY-ESO-1 antigen, including metastatic melanoma, head and neck carcinoma, sarcoma and prostate cancer (Karbach et al., 2012). The results of the trial have not been published yet.

In line with Coley's concept of using bacteria in cancer therapies, other bacterial species were evaluated

e-mail: joanna.bereta@uj.edu.pl

* Presented at 40th Jubilee Winter School of the Faculty of Biochemistry, Biophysics and Biotechnology of the Jagiellonian University "Contemporary insights into cancer. Risk, perspectives, expectations", February 16-21, 2013, Zakopane, Poland.

Abbreviations: BCG, Bacillus Calmette-Guerin; CEA, CarcinoEmbryonic Antigen; CTL, Cytotoxic T Lymphocyte; DC, Dendritic Cell; GFP, Green Fluorescent Protein; HBcAg, core antigen of hepatitis B virus; IFN $\gamma$, InterFeroN gamma; IL-12, InterLeukin 12; IL-18, InterLeukin 18; LLO, Listeriolysin; mAFP, mouse Alpha-FetoProtein, MHC, Major Histocompatibility Complex, mPSCA, mouse Prostate Stem Cell Antigen, MTD, Maximum Tolerated Dose; PAMP, Pathogen-Associated Molecular Pattern, PBS, Phosphate Buffered Saline; scFv, single chain variable fragment antibody; SCV, Salmonella-Containing Vacuole; shRNA, short hairpin RNA; Smac, Second mitochondriaderived activator of caspases; SPI, Salmonella Pathogenicity Island; STAT3, Signal Transducer and Activator of Transcription 3; T3SS, Type III Secretion System; TAA, Tumor-Associated Antigen, TNF, Tumor Necrosis Factor, TRAIL, TNF-Related Apoptosis-Inducing Ligand, Treg, regulatory T cells, TRP2, Tyrosinase-Related Protein 2, TUNEL, Terminal deoxynucleotidyl transferase dUTP Nick End Labeling, VEGFR, Vascular Endothelial Growth Factor Receptor. 
for a possible anti-tumor effect. Early experiments on "hemorrhagic allergy" in 1910s and 1920s showed that animals injected with bacterial filtrates developed hemorrhagic necrosis upon re-challenge with bacteria (so called Sanarelli-Shwartzman phenomenon). In particular, this condition was caused by Bacillus typhosus, which used to be a synonym for Salmonella Typhi at that time (Shwartzman, 1928). Interestingly, this shock syndrome induced a therapeutic effect in tumor-bearing animals (Shwartzman, 1935). However, the studies were discontinued due to very high treatment-related mortality; nowadays the adverse effects can be explained by strong stimulation of proinflammatory cytokines including tumor necrosis factor (TNF) by endotoxin and other bacterial products. Bacillus Calmette-Guerin (BCG), attenuated bovine tuberculosis bacteria (Mycobacterium bovis), has been used for decades as a vaccine protecting against tuberculosis. However, it also appeared to be one of the most successful cancer immunotherapeutics. BCG, in the form of repeated intravesical instillations, has already been in use for over 30 years as a standard method to prevent cancer recurrence after endoscopic surgery of intermediate- and high-risk non-muscle invasive bladder cancer (Kawai et al., 2013). It is also effective against inoperable bladder carcinoma in situ resulting in a 70-75\% complete response rate (Alexandroff et al., 1999). Unfortunately, in other tumor types BCG application has not proved to be more effective than conventional therapies (Alexandroff et al., 1999).

\section{BACTERIAL CANCER THERAPIES CAN ADDRESS THE KEY ISSUES IN CANCER TREATMENT}

Starting from 1946, chemotherapy gradually became the principal therapeutic strategy in cancer and bacterial therapies were largely forgotten. The success of smallmolecule drugs in cancer treatment was remarkable, but turned out to be incomplete. Chemotherapy of many tumors suffers from limited efficacy towards cancer cells and damaging action towards normal cells. Both phenomena have a significant impact on therapeutic outcomes, being responsible for incomplete tumor killing and adverse effects in other tissues. The two factors responsible for those clinical drawbacks are: low specificity towards cancer tissue and insufficient penetration of the tumor by chemotherapeutics. Cancer cells form a complex and heterogeneous system with areas of high metabolism, rich in nutrients and oxygen, as well as distal regions of poor perfusion, quiescence and necrosis (Saunders et al., 2012).

The use of bacteria as anticancer agents might have multiple advantages over other therapeutic approaches. Bacterial therapies can benefit from microbial metabolism, motility and sensitivity to address a number of issues related to currently used treatment modalities. One of the most important issues, relevant to virtually all chemotherapeutic and biological treatments, is limited accessibility of the tumor tissue to passively-distributed therapeutics. Both in the case of small molecule drugs, as well as larger molecules - cytokines, antibodies or even viruses - the therapeutic agent diffuses from the bloodstream into the periphery, with no transport system that could cross biological barriers, act against haemodynamic gradients or facilitate preferential accumulation in the tumor tissue. In fact systemic delivery of passive therapeutics produces relatively large drug concentrations in the bloodstream and relatively low drug concentrations in the tumor, resulting in limited efficacy and increased extratumoral toxicity. Bacteria offer unique mechanisms that can facilitate site-specific treatment, highly focused on the tumor and safe to other tissues. This can be possible due to several features of bacteriabased therapeutics:

\section{Environmental sensing}

Tumor tissue has a complex and heterogenic metabolism that makes it particularly resistant to systemic treatment. The natural ability of bacteria to receive signals via chemoreceptors can be used to effectively target this unique microenvironment. Oxygen concentration is one of the most important signals for anaerobic bacteria and is of particular interest in anticancer therapy since hypoxia is a common feature of tumors. Moreover, auxotrophic bacterial strains that rely on the uptake of certain metabolites can recognize the tumor microenvironment as a source of nutrients. This phenomenon can facilitate specific accumulation of bacteria in the tumor. One of the most effective examples is the use of Clostridium spores that can only germinate in oxygen-free tumor regions (Dang et al., 2001).

\section{Motility}

The bacterial microorganism is not only capable of detecting chemoattractants, but can also actively follow chemical gradients. This contrasts with passive therapeutics that simply diffuse into tissues from the circulation. Bacteria are able to penetrate deep into the tumor tissue and perform specific actions, e.g. express proteins or transfer genes, to tumor cells localized remotely from the vasculature. This feature can also allow bacteria to cross physiological barriers and accumulate in cellular regions that are either distant and inaccessible for passive therapeutics or quiescent and unresponsive to chemotherapy. For example, motile strains of Salmonella were shown to effectively penetrate tumor tissue in vitro (Toley \& Forbes, 2012). However, the role of bacterial motility in in vivo tumor localization is unclear (Stritzker et al., 2010).

\section{Active delivery}

Unlike chemical or biological molecules, microorganisms are metabolically active and are able to perform specific metabolic tasks at the tumor site. These include the production of cytotoxic agents (e.g. bacterial toxin), expression of immunomodulatory molecules (e.g. cytokine) or enzymatic conversion of a prodrug into an active therapeutic. Strains derived from intracellular pathogens can infect tumor cells and deliver specific proteins or genes to the tumor tissue (St Jean et al., 2008). Nevertheless, the intratumoral action is not always necessary as bacteria can also express tumor-related antigens to stimulate systemic anticancer immune responses. A Listeria monocytogenes-based cancer treatment that has recently entered clinical development is an example of this approach, where the bacterium delivers tumor antigens directly to the antigen presenting cells (Singh \& Wallecha, 2011).

\section{Controlled propagation}

Preferential growth in tumor tissue exhibited by many bacterial species is not exclusive to bacteria; experimental oncolytic viral therapies are based on a similar principle. However, once administered to the patient viral vectors are beyond external control. In contrast, bacterial therapeutics are susceptible to antibiotic treatment and there- 
Table 1. Overview of candidate live attenuated bacteria strains for cancer treatment.

\begin{tabular}{|c|c|c|}
\hline Parental species/strain & General features & \\
\hline Mycobacterium bovis (BCG) & $\begin{array}{l}\text { Obligate aerobe, non-motile, } \\
\text { gram-positive, facultatively } \\
\text { intracellular, pathogenic to } \\
\text { animals }\end{array}$ & $\begin{array}{l}\text { Approved for bladder cancer management as intravesical BCG thera- } \\
\text { py, proven to be more effective than intravesical chemotherapy (revie- } \\
\text { wed by Kawai et al., 2013). }\end{array}$ \\
\hline Salmonella Typhimurium ssp. & $\begin{array}{l}\text { Facultative anaerobe, motile, } \\
\text { gram-negative, facultatively } \\
\text { intracellular, broad-host } \\
\text { pathogen }\end{array}$ & $\begin{array}{l}\text { Transplantable and genetic animal tumor models in immunodeficient } \\
\text { and immunocompetent mice. } \\
\text { Completed and ongoing phase } 1 \text { clinical trials in melanoma (S. Ty- } \\
\text { phimurium VP20009) (Toso et al., 2002) and liver cancer patients (S. } \\
\text { Typhimurium x4550 expressing IL-2), respectively. }\end{array}$ \\
\hline Salmonella Typhi ssp. & $\begin{array}{l}\text { Facultative anaerobe, motile, } \\
\text { gram-negative, facultatively } \\
\text { intracellular, human-adapted } \\
\text { pathogen }\end{array}$ & $\begin{array}{l}\text { Growth inhibition of subcutaneous LM3 mammary adenocarcinoma in } \\
\text { BALB/c mice after S. Typhi CVD } 915 \text { multiple treatment (injection into } \\
\text { the tumor, peritumoral tissue and draining lymph node areas) (Ven- } \\
\text { drell et al., 2011). } \\
\text { Ongoing phase } 1 \text { clinical trial with licensed oral S. Typhi Ty21a strain } \\
\text { carrying VEGFR2 coding sequence under the control of eukaryotic pro- } \\
\text { moter for anti-angiogenic therapy and immunotherapy of pancreatic } \\
\text { cancer (Niethammer et al., 2012). }\end{array}$ \\
\hline Clostridium sp. spores & $\begin{array}{l}\text { Anaerobic, gram-positive, } \\
\text { sporulating, vegetative } \\
\text { forms are motile; pathoge- } \\
\text { nicity: } \\
\text { C. sporogenes - rarely, } \\
\text { C. novyi - yes, } \\
\text { C. beijerinckii - no }\end{array}$ & $\begin{array}{l}\text { Strains modified to deliver pro-drug converting enzymes, cytokines, } \\
\text { antibodies against tumor antigens. Spores administered systematically } \\
\text { germinate and multiply only in hypoxic/necrotic areas of tumors cau- } \\
\text { sing significant oncolysis (reviewed by Umer et al., 2012) } \\
\text { Ongoing phase } 1 \text { clinical trial of C. novyi-NT spores in patients with } \\
\text { solid tumor malignancies'. }\end{array}$ \\
\hline Escherichia coli Nissle 1917 & $\begin{array}{l}\text { Facultative anaerobe, motile, } \\
\text { gram-negative, non-patho- } \\
\text { genic probiotic strain for } \\
\text { treatment of gastrointestinal } \\
\text { disorders }\end{array}$ & $\begin{array}{l}\text { Intravenous administration of bacteria expressing azurin (apoptosis } \\
\text { inducing protein) decreased the number of lung metastases in ortho- } \\
\text { topic 4T1 breast cancer in BALB/c mice and restrained growth of sub- } \\
\text { cutaneous B16 melanoma in C57BI/6 mice (Zhang et al., 2012b). }\end{array}$ \\
\hline Escherichia coli K-12/LLO & $\begin{array}{l}\text { Strain expressing hly gene } \\
\text { encoding modified listerioly- } \\
\text { sin (LLO) lacking its N-termi- } \\
\text { nal signal sequence }\end{array}$ & $\begin{array}{l}\text { E. coli MC4100(DE3) modified with plasmid-encoded hly gene for } \\
\text { truncated listeriolysin (LLO) in order to facilitate antigen export from } \\
\text { phagosome to macrophage cytoplasm for antigen presentation in } \\
\text { association with MHC class I. Strain co-expressing LLO and truncated } \\
\text { WT1 (Wilms tumor gene 1) induced antitumor effect against WT1- } \\
\text {-expressing tumors in mice (RMA thymoma and MBL2 leukemia) thro- } \\
\text { ugh induction of CTLs and inhibition of Treg. Paraformaldehyde-fixed } \\
\text { bacteria were administered in preventive and therapeutic setting (Dai } \\
\text { et al., 2009). }\end{array}$ \\
\hline Listeria monocytogenes & $\begin{array}{l}\text { Facultative anaerobe, motile, } \\
\text { gram-positive, facultatively } \\
\text { intracellular, pathogenic to } \\
\text { animals and human, actively } \\
\text { escape into cytosol of infec- } \\
\text { ted cell }\end{array}$ & $\begin{array}{l}\text { Bacteria-mediated transfer of plasmid DNA into mammalian cells (bac- } \\
\text { tofection) (reviewed by Tangney et al., 2010). } \\
\text { Regression of established transplantable tumors and breaking im- } \\
\text { mune tolerance in genetic tumor models in mice administered with } \\
\text { L. monocytogenes dal-, dat-, and actA-deleted strain secreting HPV-16 } \\
\text { E7 antigen associated with cervix, head and neck cancer; Her-2/neu } \\
\text { breast cancer antigen or prostate specific antigen (PSA) (reviewed by } \\
\text { Paterson et al., 2010). } \\
\text { L. monocytogenes HPV-16 E7 (ADXS11-001) = ongoing phase } 2 \text { clinical } \\
\text { trial for cervical cancer and phase } 1 \text { trial for HPV-16+ oropharyngeal } \\
\text { carcinoma2. }\end{array}$ \\
\hline Shigella flexneri & $\begin{array}{l}\text { Facultative anaerobe, non- } \\
\text {-motile, gram-negative, } \\
\text { facultatively intracellular, } \\
\text { human pathogen }\end{array}$ & $\begin{array}{l}\text { Intravenous injection of S. flexneri M90T aroA mutant strain to mice } \\
\text { bearing } 4 \mathrm{~T} 1 \text { subcutaneous tumors or to spontaneous breast cancer } \\
\text { bearing transgenic MMTV-HER2 mice resulted in apoptosis and deple- } \\
\text { tion of tumor associated macrophages (TAMs), which correlated with } \\
\text { pronounced 4T1 tumor growth inhibition (Galmbacher et al., 2010). }\end{array}$ \\
\hline
\end{tabular}

'Please refer to the NCT01118819 clinical trial listed at ClinicalTrials.gov; 2Please refer to the ClinicalTrials.gov database and clinical trials no. NCT01266460 and NCT01598792, respectively

fore fully manageable in the clinical setting - therapy can be stopped at the onset of adverse effects or when the bacteria are no longer needed. In fact the use of live biotherapeutics that contain antibiotic resistance genes in clinical trials is not recommended by the regulatory agencies ${ }^{1}$.

Please refer to: Guidance for Industry: Early Clinical Trials with Live Biotherapeutic Products, US Food and Drug Administration, 2012; Environmental Risk Assessments for Medicinal Products containing, or consisting of, Genetically Modified Organisms, European Medicines Agency, 2007

\section{Immunostimulation}

Bacterial vectors augment the anti-tumor immune response not only because of their cargo but also due to their own potent immunostimulatory activity. A growing tumor creates an immunosuppressive environment and establishes immune escape mechanisms that limit the maturation of dendritic cells (DCs) as well as the priming and migration of specific $\mathrm{T}$ cells into the tumor. Bacteria provide a strong danger signal to the immune system. The specific conserved bacterial structures such as components of the cell wall or unmethylated $\mathrm{CpG}$ sites in bacterial DNA constitute so-called pathogen-associated 
molecular patterns (PAMPs) that are recognized by Tolllike receptors expressed by innate immune cells. PAMPs activate innate- and initiate adaptive immune responses. The induction of TNF, IFN $\gamma$ and IL-12 results in the recruitment and activation of DCs which upon migration to the lymph nodes may efficiently present tumor antigens to $T$ cells (Chorobik \& Marcinkiewicz, 2011). It has been shown that indeed microorganisms colonizing tumors and promoting an inflammatory reaction in the tumor microenvironment potentiate the anti-tumor host response (Avogadri et al., 2005).

The unique features of bacterial therapeutics create the opportunity for novel anticancer strategies, that combine tumor-related molecular gradients, natural bacterial features and genetic engineering. Bacteria meet all the requirements for an ideal tumor-targeting agent and might become a novel tool in the anticancer toolbox (Forbes, 2010). A summary of the bacterial strains studied in cancer treatment is shown in Table 1.

\section{SALMONELLA HAS A NUMBER OF FEATURES FAVORABLE FOR CANCER THERAPY}

Salmonella belongs to the Enterobactericae family, a group of Gram-negative, facultatively anaerobic and facultatively intracellular pathogenic bacteria. Currently, based on genome sequence similarity, the genus Salmonella is categorized into two species $S$. bongori and $S$. enterica which in turn is divided into six subspecies including $S$. enterica subsp. enterica (Tindall et al., 2005). According to the White-Kauffman-Le Minor scheme, the subspecies are classified into more than 2500 serovars by serotyping: $\mathrm{O}$-antigens (polysaccharide domain of the cell surface LPS); H1, H2 antigens (flagellin proteins) and the Vi antigen (Guibourdenche et al., 2010). New classification methods including genome-based techniques are currently under development.

In humans, Salmonella enterica subsp. enterica serovars Typhimurium and Typhi are causative agents of gastroenteritis and typhoid fever, respectively. There are more than 27 million cases of typhoid fever worldwide each year with a mortality rate of $0.8 \%$ resulting from intestinal perforation and peritonitis or severe toxic encephalopathy connected with myocarditis and hemodynamic shock (Parry et al., 2002). Infections with S. enterica serovar Typhimurium result in an estimated 94 million cases of gastroenteritis worldwide and $0.16 \%$ mortality (Feasey et al., 2012). S. Typhi is an exclusively human pathogen, while hosts of $S$. Typhimurium include rodents, poultry and cattle.

Salmonella Typhimurium and Salmonella Typhi are closely related serotypes of $S$. enterica species which differ in host adaptation and the outcome of infection. Depending on the serotype and host, Salmonella colonizes solely the intestinal epithelium leading to gastroenteritis or spreads beyond the gut mainly to liver and spleen causing typhoid fever. S. Typhimurium infection in humans is restricted to the digestive tract, with the exception of infants, elderly or immunocompromised individuals in whom it can spread, while in mice $S$. Typhimurium causes enteric fever. On the contrary, $S$. Typhi causes typhoid fever in humans but is not pathogenic to animals. In general, serotypes that lack host specificity, such as $S$. Typhimurium, are more frequently associated with disease in young rather than in adult animals, suggesting their non-optimal adaptation to mature immune system (Baumler et al., 1998).
About $90 \%$ of the genes in $S$. Typhi and $S$. Typhimurium serovars are identical (McClelland et al., 2001), but among about 4000 genes of S. Typhi, more than 200 are functionally disrupted or inactive, while most of their homologs are still fully functional in S. Typhimurium. Genes that differ include virulence factors that determine the pathogenic potential, which can in part explain the restricted host range of $S$. Typhi (McClelland et al., 2001). The majority of virulence factors are encoded by genes grouped in a few clusters in the genome, termed Salmonella Pathogenicity Islands (SPIs). S. Typhimurium and $S$. Typhi genomes share 11 SPIs, one is specific for $S$. Typhimurium (SPI14) and four are specific for $S$. Typhi (SPI7, 15, 17 and 18) (Kolyva, Waxin, and Popoff, 1992).

Salmonella sp. has an ability to multiply inside phagocytic and nonphagocytic cells including macrophages, dendritic cells (DCs), neutrophils, M cells and epithelial cells (Malik-Kale et al., 2011). The ability of Salmonella to invade and survive within a host cell is dependent on two Type III Secretion Systems (T3SS), the multiprotein complexes with a needle-like structure present on the bacteria cell wall. Proteins involved in the assembly of the two major T3SSs of Salmonella are encoded by SPI1 and SPI2. T3SS1, encoded by SPI1, is required for efficient invasion of nonphagocytic cells. In contrast, the expression of SPI2-encoded T3SS2 is induced following the internalization of Salmonella into host cells and is required for post-invasion processes (Velge et al., 2012). During the invasion, some SPI1 encoded proteins such as InvG, InvJ, PrgH, PrgI, PrgK and SpaO are responsible for the assembly of the needle complex, whereas others, including SipB, SipC and SipD, translocate the effector proteins through this needle. Regulation of gene expression in response to the surrounding microenvironment depends on several two-component systems, such as PhoQ/PhoP whose expression is induced by $\mathrm{Mg}^{2+}$ starvation and low pH (Lucas et al., 2000). Another system, OmpR-EnvZ, responds to changes in osmolarity and regulates invasion (Bajaj et al., 1995) as well as intracellular survival. Upon internalization, Salmonella modifies the phagosome into a Salmonella-Containing Vacuole (SCV), which is characterized by the presence of some lysosomal membrane proteins, low $\mathrm{pH}$, and transient interactions with the endocytic pathways. At early stages of maturation, SCV recruits and quickly looses early endocytic markers, such as the early endosomal antigen 1 (EEA-1) or transferrin receptor (TfR) (Steele-Mortimer et al., 1999). At later points of maturation it acquires several late endosomal markers, including LAMP1 (Lysosomal-Associated Membrane Protein 1) (Steele-Mortimer, 2008). Bacterial replication is accompanied by the formation of dynamic membrane tubules termed SalmonellaInduced Filaments, which extend from SCV throughout the cell (Schroeder et al., 2011). The maturation of SCV is controlled by SPI2-encoded effectors which allow bacteria to avoid phagosome-lysosome fusion and degradation and protect them against reactive oxygen and nitrogen species (Chakravortty et al., 2002; Janssen et al., 2003).

After the ingestion of $S$. enterica, the bacteria use different routes to cross the intestinal barrier. The main route leads through the receptor-mediated endocytosis by microfold cells (M-cells) in Peyer's patches (Jepson \& Clark, 2001), independently of SPI1 and SPI2 (MartinezArgudo \& Jepson, 2008). Then the bacteria are taken up by the underlying macrophages. Enterocytes of the intestinal epithelium, except for the M cells, engulf Salmonella by macropinocytosis in a SPI1-dependent manner. The 
bacteria can be also engulfed by DCs (Swart \& Hensel, 2012). In epithelial cells $S$. Typhimurium can reside and replicate in SCV, as well as in the cytosol (Malik-Kale et al., 2012); however, these two intracellular populations of bacteria are transcriptionally distinct: the intravacuolar bacteria are SPI2-induced, while the cytosolic bacteria are SPI1-induced and flagellated (Knodler et al., 2010). Salmonella induces caspase-1 and -2 mediated apoptosis of infected macrophages and epithelial cells (Jesenberger et al., 2000; Kim et al., 1998; Monack et al., 1996). Apoptosis depends mainly upon the SPI1 effector protein, SipB, delivered to the host cell by SPI1-encoded T3SS (Jesenberger et al., 2000). Bacteria, engulfed by macrophages and DCs spread from Peyer's patches to mesenteric lymph nodes, spleen and liver. The ability of Salmonella to elicit systemic disease is serovar-dependent and correlates with its capability to survive and replicate inside the host cell and to avoid the host adaptive immune response (reviewed by Swart \& Hensel, 2012).

\section{THERAPEUTIC SALMONELLA STRAINS ARE DERIVED FROM S. TYPHIMURIUM OR S. TYPHI}

$S$. Typhimurium infection in mice remains the dominant animal model of typhoid fever because it leads to comparable systemic disease with dissemination of bacteria to the lymphatic system and peripheral organs. Hence the prevalence of $S$. Typhimurium-based tumor therapeutic vectors studied in murine models of cancer. The choice of $S$. Typhimurium over $S$. Typhi for preclinical research on cancer therapy could be arguable but is legitimated by the availability of suitable animal models. Some improvement was made by the development of a transgenic mouse model of $S$. Typhi infection (Song et al., 2010), but it has not been applied to Salmonellabased tumor therapy studies yet. Nevertheless, a superior induction of immune response to heterologous antigen delivered by an orally administered vaccine strain of $S$. Typhimurium over $S$. Typhi was shown in a clinical trial (Angelakopoulos \& Hohmann, 2000). Both serotypes are amenable to genetic modifications of virulence and in terms of safety are equally eligible as live attenuated therapeutic strains. There has already been some success in the clinical use of attenuated Salmonella strains. S. Typhimurium VNP20009 was shown to be safe when administered to cancer patients (Toso et al., 2002) and $S$. Typhi Ty21a, a live attenuated oral vaccine against typhoid fever, has already been applied for more than 30 years to adults and children above 6 years of age who are at risk of $S$. Typhi exposure. A phase I clinical trial evaluating the safety, tolerability, and effects of the $S$. Typhi Ty21a strain used as a DNA delivery vehicle in cancer patients has been announced (Niethammer et al., 2012) but its results are not yet available.

Attenuation of virulence is crucial for the development of new Salmonella-based vector strains in order to elicit an appropriate profile of the immune response. Up to date about 50 genes of Salmonella spp. have been proven to be feasible for inactivation in order to obtain an attenuated derivative with modified virulence or metabolic functions. Gene inactivation is achieved by laboratory selection of the desired phenotype, for example by passaging bacteria through selective conditions and screening for survivors, or is the result of site-directedor chemical mutagenesis. Inactivation of genes coding for proteins involved in metabolic pathways generates auxotrophic strains, i.e. dependent on external sources of nutrients, for example aromatic amino acids (aro mu- tants) or purines (pur mutants). Direct attenuation of virulence involves inactivation of genes encoding proteins interacting with the infected organism or factors regulating their expression. The latter include: (i) $p h o P$ and/ or $p h \circ Q$, which regulate expression of many genes, e.g. those contributing to the resistance against antimicrobial peptides and genes located in pathogenicity islands, (ii) cya and crp genes coding for global regulatory factors involved in expression of many proteins of cellular catabolism, (iii) btrF gene, which enables survival under stress conditions (Garmory et al., 2002; Raupach \& Kaufmann, 2001; Raupach et al., 2003). The attenuating mutations introduced into Salmonella experimental strains are summarized in Table 2.

An interesting example comes from a sophisticated work of Robert Hoffman's group: A1-R is an auxotrophic Salmonella strain developed for increased tumor targeting and limited toxicity. First, the researchers obtained an A1 auxotrophic strain dependent on an external source of leucine and arginine by nitrosoguanidine (NTG) mutagenesis of $S$. Typhimurium 14028-GFP. To further enhance tumor targeting of S. Typhimurium A1, bacteria were injected i.v. into nude mice bearing HT-29 human colon adenocarcinoma. GFP-expressing bacteria isolated from the excised infected tumors, were termed A1-R and had an increased ability to adhere to cancer cells; the number of A1-R bacteria attached to HT-29 cells in vitro was approximately six times higher than that of the parental A1 strain (Zhao et al., 2006).

$S$. Typhimurium A1-R was tested in numerous human tumor xenografts in nude mice, such as MARY-X breast tumor (Zhao et al., 2006), orthotopic prostate PC-3 cancer (Zhao et al., 2007), orthotopic human pancreatic cancer (Nagakura et al., 2009), orthotopic U87 spinal cord glioma (Kimura et al., 2010), orthotopic MDA-MB-435 breast cancer (Zhang et al., 2012a), lung fibrosarcoma (Hayashi et al., 2009b) and lung osteosarcoma (Hayashi et al., 2009a) resulting in a significant tumor growth inhibition in all tested models, with complete tumor regression in a few of them.

Applicability of A1-R in metastatic disease has also been tested. Hayashi et al. (2009b) developed a lymph node metastasis model of human pancreatic cancer (XPA-1) by injecting XPA-1 cells into the inguinal lymph node of nude mice which resulted in tumor growth in the axillary lymph node. Five of six mice had their lymph node metastases eradicated within 7-21 days after intravenous treatment with A1-R in contrast to growing metastases in the untreated control group (Hayashi et al., 2009b).

A1-R has also been tested in immunocompetent mice bearing murine Lewis lung carcinoma (Tome et al., 2013). The authors proposed to apply a priming dose of $1 \times 10^{6}$ cfu followed, 4 hours later, by a therapeutic dose of $1 \times 10^{7} \mathrm{cfu}$ of A1-R. The priming dose resulted in an elevated serum level of TNF and tumor vessel destruction, which could facilitate the invasion of tumor by bacteria.

As it can be expected, the mode of attenuation affects the quality of the anti-Salmonella immune response. While cytokines of the Th1 type (IFN $\gamma$, IL-12, IL-18) are crucial for protection against Salmonella in mice and humans, different mutant Salmonella strains require alternative cytokines for the control of infection. Studies with knockout mice showed that IFN $\gamma$ and TNF were essential for the early control of infection with both wild type and aro $A$ mutant strains. In contrast, TNF was not required for the clearance of the aro $A$ mutant (Raupach \& Kaufmann, 2001). 
Table 2. Attenuated strains of $S$. Typhimurium developed as bacterial vaccine vectors.

\begin{tabular}{|c|c|c|}
\hline Parental strain & Modified strain & \\
\hline ATCC 14028 & A1-R & leucine and arginine auxotrophs (Zhao et al., 2005) \\
\hline SL1344 & BRD509 & $\begin{array}{l}\operatorname{aro} A \text { aro } D \\
\text { aromatic compound dependent (Strugnell et al., 1992) }\end{array}$ \\
\hline $\begin{array}{l}\text { NCTC12023 } \\
\text { (ATCC 14028) }\end{array}$ & MvP728 & $\begin{array}{l}\text { purD htrA } \\
\text { adenine dependent; defective intra-macrophage survival (Xiong et al., 2010) }\end{array}$ \\
\hline Not stated & $\operatorname{Re} 88$ & $\begin{array}{l}\text { aroA dam (Xiang et al., 2001) } \\
\text { DNA adenine methylase mutants are defective in protein secretion, cell invasion } \\
\text { and } M \text { cell cytotoxicity }\end{array}$ \\
\hline SL3261 & SB824 & aroA sptP (encodes virulence protein SptP) (Panthel et al., 2005) \\
\hline $14028 s$ & SHJ2037 & 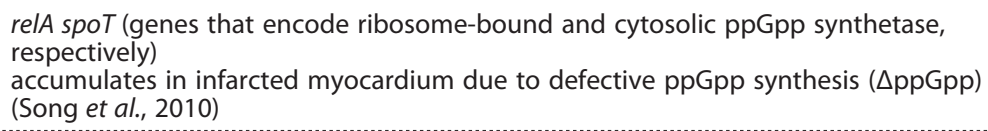 \\
\hline SL1346 & SL3261 & $\operatorname{aro} A$ (Meng et al., 2010) \\
\hline 2337-65 (WRAY) & SL7207 & $\begin{array}{l}\operatorname{aro} A \\
\text { dependent on } p \text {-aminobenzoate and 2,3-dihydroxybenzoate for the synthesis of } \\
\text { aromatic amino acids; these two compounds are not available in a mammalian } \\
\text { host (Hoiseth \& Stocker, 1985) }\end{array}$ \\
\hline ATCC 14028 & VNP20009 (YS1646) & $\begin{array}{l}\text { msbB purl } \\
\text { purine dependent; reduced ability to induce septic shock due to altered lipid A } \\
\text { structure (Low et al., 2004) }\end{array}$ \\
\hline SL7207 & YB1 & $\begin{array}{l}\text { aroA } \\
\text { modified to express asd essential gene under hypoxia-induced promoter (Yu et al., } \\
2012 \text { ) }\end{array}$ \\
\hline UK-1 & $X 4550$ & $\begin{array}{l}\text { cya crp asd (Saltzman et al., 1996) } \\
\text { adenylate cyclase and cyclic AMP receptor protein mutants are avirulent in mice }\end{array}$ \\
\hline
\end{tabular}

Attenuated Salmonella strains preferentially colonize solid tumors and inhibit their growth in animal models (Bermudes et al., 2002; Pawelek et al., 1997; Zhao et al., 2005). In some therapeutic approaches attenuated strains were used without any further modifications to exert tumor-directed cytotoxic effects and induce proper antitumor immune response. Apart from the A1-R strain described above also the application of the $S$. Typhimurium X9241 strain brought successful results. Bacteria injected intratumorally to CT26 tumors or CT26 tumors expressing human tumor antigen, Her-2/neu, significantly inhibited tumor growth. Surprisingly, they did not potentiate tumor-antigen-specific cellular immunity. However, they induced an important functional shift in the phenotype of tumor-infiltrating $\mathrm{CD}_{11} \mathrm{~b}^{+} \mathrm{Gr}-1^{+}$subpopulation of leukocytes (myeloid derived suppressor cells, MDSC) towards immunogenic TNF-secreting neutrophils. Moreover, the therapy reduced the percentage of regulatory $\mathrm{T}$ cells which may promote tumor development (Hong et al., 2013).

Thanks to the intracellular lifestyle and immunomodulatory properties attenuated Salmonella strains are also used as vectors for the delivery of therapeutic molecules. The cargo is a genetic material which codes for proteins including tumor antigens (described in the next chapter), cytokines, apoptosis-inducing factors, prodrug-converting enzymes, or short hairpin RNAs (shRNAs) able to silence expression of a protein of choice. Numerous approaches were developed to enhance and navigate the immunomodulatory properties of Salmonella through genetic modifications that ensure the delivery of proapoptotic molecules or cytokines straight to the tumor, which limits their potential undesired systemic side effects. The examples are listed in Table 3.

The group of John C. Reed demonstrated a significant increase in tumor growth inhibition by a Salmonella strain expressing IL-18 in immunocompetent mice (Loeffler et al., 2008). The modified and parental strains showed comparable toxicity limited to the spleen and liver. IL-18 stimulates $\mathrm{T}$ cell and NK cell to proliferation, cytotoxicity and cytokine production. Administration of IL-18-secreting Salmonella did not improve tumor infiltration by $\mathrm{CD}^{+} \mathrm{T}$ lymphocytes but led to increased infiltration by granulocytes, $\mathrm{CD}^{+} \mathrm{T}$ cells and $\mathrm{DX}^{+} \mathrm{NK}$ cells, when compared to Salmonella control strain (Loeffler et al., 2008).

In order to enhance the proapoptotic activity of $S$. Typhimurium towards infected cancer cells several research groups took an advantage of apoptosis-inducing factors and equipped bacteria with appropriate expression vectors. TRAIL (TNF-related apoptosis-inducing ligand) has a capacity to selectively induce apoptosis in a wide variety of cancer cells but hardly in normal cells which makes it a promising cancer therapeutic (Hylander et al., 2005; Shanker et al., 2008; Walczak et al., 1999; Yagita et al., 2004). Similarly to TNF, TRAIL exerts its proapoptotic effect through the death receptor-dependent pathway which activates the caspase cascade (LeBlanc \& Ashkenazi, 2003).

Ganai et al. (2009) constructed an expression vector placing TRAIL under the promoter of $\operatorname{rec} A$ gene involved in the prokaryotic SOS response to DNA damage (Anderson \& Kowalczykowski, 1998). It created a radiation-inducible system, where expression of TRAIL was turned on by genotoxic damage evoked by radiation. Such a system enables temporal and spatial control of the gene expression, additionally increasing the selectivity of the therapy towards cancer cells subjected to radiotherapy. Intravenous administration of $S$. Typhimurium VNP20009 equipped with a PrecA-TRAIL construct (VNP/pRE-TR) into Balb/c mice bearing subcutaneous 4T1 mammary carcinoma followed by 2 Gy whole body 
Table 3. Therapeutic approaches based on S. Typhimurium modified to deliver apoptosis inducing or immune modulatory factors.

\begin{tabular}{|c|c|c|c|c|c|}
\hline Vector & Cargo & Mouse strain & & Therapeutic scheme & \\
\hline \multirow[t]{2}{*}{ BRD509 } & \multirow{2}{*}{$\begin{array}{l}\text { CDNA for TNF fu- } \\
\text { sed to } 160 \text { amino } \\
\text { acid residue-N- } \\
\text {-terminal fragment } \\
\text { of SipB under the } \\
\text { control of bacterial } \\
\text { lac promoter }\end{array}$} & $\mathrm{C} 57 \mathrm{BI} / 6$ & $\begin{array}{l}\text { s.c. TC-1 cervical } \\
\text { tumor, B16F10 } \\
\text { melanoma }\end{array}$ & \multirow{2}{*}{$\begin{array}{l}\text { Two s.c. injections of } 10^{8} \\
\text { CFU/mouse } 7 \text { and } 14 \text { days } \\
\text { after s.C. inoculation of } \\
10^{5} \text { B16F10 }\end{array}$} & \multirow{2}{*}{$\begin{array}{l}\text { Complete inhibition of } \\
\text { tumor cell growth in } 90 \% \\
\text { of animals, but these mice } \\
\text { were not protected against } \\
\text { second B16F10 challenge. } \\
\text { Reduced growth of all listed } \\
\text { tumors, although with diver- } \\
\text { se efficacy (Yoon et al., 2011) }\end{array}$} \\
\hline & & $\mathrm{BALB} / \mathrm{c}$ & $\begin{array}{l}\text { s.c. } 4 \mathrm{~T}-1 \text { breast } \\
\text { cancer, CT26 co- } \\
\text { lon cancer, and } \\
\text { RENCA kidney } \\
\text { carcinoma }\end{array}$ & & \\
\hline SL7207 & $\begin{array}{l}\text { TRAIL and apoptin } \\
\text { genes under the } \\
\text { control of eukary- } \\
\text { otic promoters }\end{array}$ & BALB/c nude & $\begin{array}{l}\text { s.c. SGC-7901 } \\
\text { human gastric } \\
\text { cancer }\left(5 \times 10^{5}\right. \\
\text { cells })\end{array}$ & $\begin{array}{l}\text { Intratumoral injection } 7 \\
\text { days after tumor implan- } \\
\text { tation, repeated every } 7 \\
\text { days }\left(2 \times 10^{6} \mathrm{CFU}\right)\end{array}$ & $\begin{array}{l}\text { Cancer cell apoptosis in } \\
\text { tumor tissue and tumor } \\
\text { regression (Cao et al., 2010) }\end{array}$ \\
\hline $\begin{array}{l}\text { VNP20009 } \\
\text { and MVP728 }\end{array}$ & $\begin{array}{l}\text { Stat3 shRNA and } \\
\text { survivin expressing } \\
\text { plasmid }\end{array}$ & C57BI/6 & $\begin{array}{l}\text { S.C. B16F10 me- } \\
\text { lanoma } \\
\left(10^{5} \text { cells }\right)\end{array}$ & $\begin{array}{l}\text { YS1646 with Stat } 3 \text { shRNA } \\
\text { i.v. injected at } 10^{7} \text { CFU } \\
\text { when tumor volumes } \\
\text { were } 50 \mathrm{~mm}^{3} \text { or above } \\
\text { ( } 7-8 \mathrm{~mm} \text { diameter), fol- } \\
\text { lowed by oral gavage } \\
\text { with } 10^{7} \text { CFU of MVP728 } \\
\text { with survivin expression } \\
\text { plasmid }\end{array}$ & $\begin{array}{l}\text { Enhancement of CD4+ and } \\
\text { CD8+ T lymphocytes infil- } \\
\text { tration into tumors, incre- } \\
\text { ased tumor cell apoptosis, } \\
\text { suppression of s.C. B16F10 } \\
\text { melanoma growth (Manuel } \\
\text { et al., 2011) }\end{array}$ \\
\hline \multirow[t]{3}{*}{ VNP20009 } & \multirow{3}{*}{$\begin{array}{l}\text { cDNA for IL-18 } \\
\text { fused to N-terminal } \\
\text { leader sequence } \\
\text { for directing se- } \\
\text { cretion, under the } \\
\text { control of bacterial } \\
\text { ompC promoter }\end{array}$} & $\mathrm{BALB} / \mathrm{c}$ & $\begin{array}{l}\text { s.c. CT26 colon } \\
\text { carcinoma }\left(10^{5}\right. \\
\text { cells) }\end{array}$ & $\begin{array}{l}\text { i.v. injection of } 5 \times 10^{6} \\
\text { CFU when tumors were } \\
\text { visible ( } 14 \text { days after ino- } \\
\text { culation) }\end{array}$ & $\begin{array}{l}\text { Reduced tumor growth, } \\
\text { leukocyte infiltration into } \\
\text { tumors, increased intra- } \\
\text { tumoral level of IL-1 } \beta \text {, TNF, } \\
\text { IFNy }\end{array}$ \\
\hline & & $\mathrm{BALB} / \mathrm{c}$ & $\begin{array}{l}\text { S.C. D2F2 breast } \\
\text { carcinoma }(2.5 \\
\left.\times 10^{5} \text { cells }\right)\end{array}$ & $\begin{array}{l}\text { i.v. injection of } 5 \times 10^{6} \\
\text { CFU on day } 9,14 \text { and } 19 \\
\text { after tumor inoculation }\end{array}$ & $\begin{array}{l}\text { Significant tumor growth } \\
\text { inhibition }\end{array}$ \\
\hline & & C57BI/6 & $\begin{array}{l}\text { i.v. Lewis lung } \\
\text { carcinoma }(5 \times \\
\left.10^{4} \text { cells }\right)\end{array}$ & $\begin{array}{l}\text { i.v. injection } 6,13 \text {, and } \\
20 \text { days after tumor cells } \\
\text { injection }\end{array}$ & $\begin{array}{l}\text { Reduced tumor burden in } \\
\text { lungs (Loeffler et al., 2008) }\end{array}$ \\
\hline VNP20009 & $\begin{array}{l}\text { IDO shRNA (immu- } \\
\text { nosuppressive mo- } \\
\text { lecule indoleamine } \\
2,3 \text { dioxygenase 1) }\end{array}$ & C57BI/6 & $\begin{array}{l}\text { s.c. B16F10 me- } \\
\text { lanoma }(2.5 \times \\
\left.10^{5} \text { cells }\right)\end{array}$ & $\begin{array}{l}2.5 \times 10^{6} \text { CFU injected } \\
\text { intravenously twice, } 4 \\
\text { days apart, into mice with } \\
\text { tumor diameters equal or } \\
\text { greater than } 7 \mathrm{~mm}\end{array}$ & $\begin{array}{l}\text { Synergistic effect of IDO } \\
\text { silencing and S. } \\
\text { Typhimurium on tumor } \\
\text { growth suppression. Incre- } \\
\text { ased tumor influx of } \\
\text { PMNs and intratumoral } \\
\text { cell death. Tumor growth } \\
\text { suppression occurred also } \\
\text { in the absence of functional } \\
\text { adaptive immunity (Blache } \\
\text { et al., 2012) }\end{array}$ \\
\hline VNP20009 & $\begin{array}{l}\text { TRAIL under the } \\
\text { control of bacterial } \\
\text { anaerobic-inducible } \\
\text { nirB promoter }\end{array}$ & C57BI/6 & $\begin{array}{l}\text { s.c. B16F10 me- } \\
\text { lanoma }\left(5 \times 10^{5}\right. \\
\text { cells) and RM-1 } \\
\text { prostate cancer } \\
\left(2 \times 10^{5} \text { cells }\right)\end{array}$ & $\begin{array}{l}\text { i.p. injection of } 10^{5} \mathrm{CFU} \\
\text { per mouse on day } 7 \text { for } \\
\text { B16F10 or day } 9 \text { for RM- } 1 \\
\text { after tumor inoculation }\end{array}$ & $\begin{array}{l}\text { Increased levels of TRAIL in } \\
\text { B16F10 tumor but not in } \\
\text { liver or spleen and tumor } \\
\text { growth inhibition. VNP-TRAIL } \\
\text { was not more effective in } \\
\text { tumor growth suppression } \\
\text { of TRAIL-resistant RM-1 tu- } \\
\text { mors than VNP control strain } \\
\text { (Chen et al., 2012) }\end{array}$ \\
\hline \multirow[t]{2}{*}{ VNP20009 } & \multirow[t]{2}{*}{$\begin{array}{l}\text { CCL21 under the } \\
\text { control of bacterial } \\
\text { ompC promoter }\end{array}$} & \multirow[t]{2}{*}{$\mathrm{BALB} / \mathrm{c}$} & $\begin{array}{l}\text { s.c. CT26 colon } \\
\text { carcinoma }(2.5 \\
\left.\times 10^{5} \text { cells }\right)\end{array}$ & $\begin{array}{l}\text { Intravenous injection } 9 \\
14 \text { and } 19 \text { days after tu- } \\
\text { mor inoculation }\end{array}$ & \multirow[t]{2}{*}{$\begin{array}{l}\text { Significantly inhibited } \\
\text { growth of subcutaneous tu- } \\
\text { mors and pulmonary tumor } \\
\text { foci (Loeffler et al., 2009) }\end{array}$} \\
\hline & & & $\begin{array}{l}\text { i.v. D2F2 breast } \\
\text { carcinoma ( } 5 \\
\times 10^{4} \text { cells) for } \\
\text { pulmonary tu- } \\
\text { mor model }\end{array}$ & $\begin{array}{l}\text { i.v. injection of } 5 \times 10^{6} \\
\text { CFU at day } 6,13 \text {, and } 20 \\
\text { after tumor cells injection }\end{array}$ & \\
\hline
\end{tabular}

$\gamma$-irradiation 2 days later resulted in a significant decrease in tumor growth. The combined treatment increased the tumor size doubling time by $50 \%$ compared to VNP/ pRA-TR treatment alone and by $100 \%$ in comparison to PBS control. The combined therapy has a synergistic effect since irradiation alone barely influenced tumor growth (Ganai et al., 2009).
A similar approach was exploited by Chen et al. (Chen et al., 2012) who placed TRAIL cDNA under the control of nirB promoter induced by hypoxic conditions (Chatfield et al., 1992). The S. Typhimurium VNP20009 strain carrying TRAIL expression vector was intraperitoneally administered to B16F10 melanoma-bearing C57BL/6 mice. Significant inhibition of melanoma tumor growth 
and extended survival time were observed. The TUNEL assay showed that the therapeutic effect of modified bacteria was associated with a significant increase in apoptosis of melanoma cells compared to mice receiving the control strain. Importantly, the immunohistochemical study revealed that indeed TRAIL was preferentially expressed in the hypoxic, necrotic area of the tumor, and not in the oxygenated liver or spleen, which may explain limited toxicity of TRAIL in normal tissues.

It has been shown that Smac (second mitochondriaderived activator of caspases) is involved in TRAIL-induced apoptosis and may affect the efficiency of TRAILbased therapies (Deng et al., 2002; Zhang et al., 2001). Also in vivo studies showed that complete regression of established glioma in a mouse model was achieved only when TRAIL therapy was associated with Smac administration (Fulda et al., 2002; Pei et al., 2004). Fu et al. (2008) took an advantage of this observation and engineered a modified S. Typhimurium SL3261 strain carrying a dual-gene vector coding for both Smac and TRAIL. The cDNAs were placed under the promoter of human telomerase reverse transcriptase, highly active in majority of cancers and generally inactive in normal differentiated cells (Kim et al., 1998). LL/2 Lewis lung carcinoma, B16F10 melanoma and 4T1 mammary carcinoma cells infected with the modified bacteria showed high expression levels of both proteins accompanied by a high rate of apoptosis. Moreover, oral administration of the modified strain significantly suppressed tumor growth in all tested mice models (LL/2, B16F10, 4T1), without any observable side-effects. The volumes of the tumors were lowered approximately by $65-75 \%$ compared to groups treated with a control strain and by $90 \%$ compared to PBS-treated animals.

Cao et al. (2010) applied combination of TRAIL with another apoptosis-inducing factor — apoptin (VP3), a protein of the chicken anemia virus proved to promote tumor cell-specific apoptosis in a p53-independent manner (Zhuang et al., 1995). The study showed that intratumoral administration of S. Typhimurium SL7207 carrying apoptin and TRAIL coding sequences under the control of eukaryotic cytomegalovirus immediate early promoter to human gastric tumor xenografts in nude mice resulted in increased effectiveness of bacteria-mediated tumor growth suppression, with complete tumor regression in some animals. TUNEL assays in tissue sections showed a higher apoptotic rate in mice treated with $S$. Typhimurium SL7207 carrying apoptin and TRAIL genes compared to a control strain (Cao et al., 2010).

\section{SALMONELLA CAN BE ALSO USED AS A TUMOR VACCINE VECTOR}

The vast majority of tumors express proteins or other antigens that are absent (or present only in very low quantities) in healthy adult tissues. These tumor-associated antigens (TAAs) are potentially immunogenic and tumor development is usually accompanied by specific, although often ineffective, anti-TAA immune response. TAA vaccines used for cancer therapy often fail, probably due to inadequate antigen presentation and insufficient activation of innate immunity. The application of Salmonella as a vector for TAAs should result in overcoming both impediments. The first attempts to deliver TAA via Salmonella were undertaken in late 1990s. From that time numerous studies utilizing natural (mPSCA, mAFP, survivin, endoglin) or artificial ( $\beta$-galactosidase) tumor antigens have proved that placing a TAA-coding transgene under strong cytomegalovirus promoter in a plasmid carried by Salmonella allows for TAA expression in the cytoplasm of infected cells or dendritic cells which engulfed the infected, apoptotic cells (Paglia et al., 1998; Yrlid \& Wick, 2000); TAA expression elicits efficient cell-mediated or both cell-mediated and humoral immune responses (Ahmad et al., 2011; Chou et al., 2006; Fest et al., 2009; Huebener et al., 2008; Jarosz et al., 2013; Paglia et al., 1998). However, this is not always the case. The group of Dai-Ming Fan transformed Salmonella with a plasmid, which expressed a fusion protein consisting of a mimotope of the gastric tumor antigen, MG2 with either PADRE T helper epitope (Guo et al., 2003) or $\mathrm{HBcAg}$, a strong Hepatitis B virus T-cell-dependent and T-cell-independent antigen (Meng et al., 2005). Although oral administration of either Salmonella strain resulted in a partial inhibition of the growth of the subsequently injected Ehrlich ascites carcinoma, only the humoral but not the cell-mediated response against MG2 could be detected (Guo et al., 2003; Meng et al., 2005).

It is believed that intracellular location of Salmonella within phagosomes may limit the ability to generate a MHC class I-restricted immune response towards transgene-encoded proteins. However, Salmonella expresses a multi-protein complex, T3SS, to deliver some bacterial effector proteins into the host cell in order to modulate its functions and create a microenvironment favorable for bacterial survival and proliferation (Galan and Collmer, 1999). A special N-terminal signal sequence directs bacterial proteins for export through T3SS to the host cell cytoplasm. This very mechanism was employed by several research groups to deliver Salmonella plasmidencoded tumor antigens to the host cell cytoplasm and thus make them available for the MHC class I presentation. Instead of sequences encoding TAAs alone, the constructs coding for chimeric proteins consisting of a tumor antigen preceded by an N-terminal fragment of a bacterial protein subjected to T3SS export (containing secretion and translocation signals) were placed in the Salmonella plasmid. These included peptides derived from the SopE, SseF and YopE proteins (Jellbauer et al., 2012; Manuel et al., 2011; Nishikawa et al., 2006; Zhu et al., 2010). The chimeric transgenes were usually placed under bacterial promoters activated after invasion of the host cell.

This approach was applied by Nishikawa et al. in an attempt to generate a therapeutic vaccine against cancers overexpressing the NY-ESO-1 antigen (Nishikawa et al., 2006). This germ cell antigen seems to be a proper target for immunotherapy, since it is expressed by a broad variety of tumors but not by normal somatic cells. Following oral administration of the Salmonella-based vaccine that delivered NY-ESO-1 and assured its cytoplasmic localization, $\mathrm{CD}^{+} \mathrm{T}$ cell-dependent regression of established NY-ESO-1-expressing tumors was observed. What is more, the vaccine was able to initiate a process known as epitope spreading and was therefore effective even towards tumors lacking the NY-ESO-1 antigen. Intratumoral injection of this Salmonella strain delivering the antigen and engaging pre-existing NY-ESO-1-specific $\mathrm{CD}^{+} \mathrm{T}$ cells resulted in tumor regression and activation of subsets of $\mathrm{T}$ cells recognizing at least two different tumor antigens that were not delivered by Salmonella $(\mathrm{Ni}-$ shikawa et al., 2006).

A more complex transgene was introduced into a Salmonella plasmid by Zhu et al., who worked on an efficient anti-melanoma vaccine (Zhu et al., 2010). It encoded a fusion protein consisting of the secretion and translocation signals of SopE and a fragment of the 
melanoma-specific TRP2 (tyrosinase-related protein 2) antigen containing three immunodominant epitopes. The presence of Hsp70, often referred to as immunochaperone, facilitates the proper presentation of antigenic peptides to cytotoxic $T$ cells and may therefore enhance the anti-melanoma immune response. This vaccine induced a specific CTL response against B16F10 melanoma and showed strong protective as well as therapeutic effects (Zhu et al., 2010).

Another modification aiming in augmenting the presentation of Salmonella-delivered neuroblastoma antigens was proposed by the group of Lode (Fest et al., 2009; Huebener et al., 2008). The chimeric protein encoded by Salmonella plasmid contained a stably ubiquitinated tumor antigen, either tyrosine hydroxylase- (Huebener et al., 2008) or survivin (Fest et al., 2009) fragments. The presence of ubiquitin guaranteed proteasomal degradation of proteins encoded by the transgenes and increased MHC I-mediated peptides presentation. This approach led to significant $\mathrm{CD}^{+} \mathrm{T}$ cell-dependent inhibition of neuroblastoma growth (Fest et al., 2009; Huebener et al., 2008) and decreased the rate of metastasis (Huebener et al., 2008) or tumor growth upon rechallenge (Fest et al., 2009).

Manuel et al. also chose survivin as an excellent target for tumor therapy (Manuel et al., 2011). This antiapoptotic protein is expressed at a low level in normal adult tissues but is abundant in essentially all solid tumors (Altieri, 2003), as well as in endothelial cells during angiogenesis (Tran et al., 1999). However, unlike their predecessors, the researchers utilized bacterial promoter to express a codon-optimized transgene in Salmonella and used the SseF secretion signal to transport survivin to the cytoplasm of the infected cells. The combined therapy consisting of sequential intravenous injection of two Salmonella strains: the first encoding shRNA targeting a tolerogenic transcription factor, and the second coding for SseF-survivin, turned out to be effective even in the case of large, well-established melanoma tumors. The silencing of STAT3 expression, crucial for this very promising result, led to increased proliferation of intratumoral $\mathrm{CD}^{+}$and $\mathrm{CD}^{+} \mathrm{T}$ cells and elevated levels of granzyme B (Manuel et al., 2011).

Not only survivin but also other proteins overproduced in endothelium during angiogenesis, such as VEGFR2, one of the VEGF receptors, or endoglin, a component of the TGF $\beta$ (Transforming Growth Factor beta) receptor complex, have been chosen as targets for Salmonella-based vaccines (Jarosz et al., 2013; Jellbauer et al., 2012). The induction of the CTL response against these antigens should reduce angiogenesis and destroy tumor vasculature leading to inhibition of tumor development. Indeed, Salmonella carrying a plasmid encoding a fusion protein comprising the YopE secretion sequence and the fragment of VEGFR2 containing the CD8+ Tcell epitope efficiently limited the growth of B16F10 melanoma in both prophylactic and therapeutic settings (Jellbauer et al., 2012). The authors hypothesized that the vaccine may also affect the immunosuppresive tumor microenvironment by destroying the VEGFR2-positive subset of Treg lymphocytes.

Similarly, a combined therapy using orally applied Salmonella carrying endoglin cDNA with an intratumorally injected plasmid coding for interleukin-12 reduced microvessel density and diminished the number of Tregs within B16F10 tumors resulting in inhibition of the tumor growth and prolonged survival of mice (Jarosz et al., 2013).
Some examples of in vivo studies on the efficacy of various Salmonella Typhimurium-based anti-cancer vaccines are presented in Table 4.

Recently, a phase 1 clinical trial evaluating the safety of the first Salmonella Typhi-based oral vaccine coding for the full length human VEGFR2 and aimed at eliciting an anti-VEGFR2 immune response has started and involves patients suffering from pancreatic cancer. The results of this trial are not yet available (Niethammer et al., 2012).

\section{CLINICAL STUDIES INDICATE TUMOR TARGETING AS THE MAJOR LIMITATION OF SALMONELLA-BASED THERAPIES}

The mouse is a natural host for Salmonella enterica serovar Typhimurium and this species is considered to be the most sensitive to VNP20009 infections. However, the maximum tolerated dose (MTD) of VNP20009 in mice is large and was estimated to be $0.5 \times 10^{8}$ colony forming units per $\mathrm{kg}$ of body weight, which makes this attenuated strain at least 50000 times less virulent than the parental Salmonella (Lee et al., 2000). Importantly, similar values of MTD were estimated for other species - dogs, pigs and monkeys $\left(3.0 \times 10^{7}, 1.9 \times 10^{8}\right.$ and $2.5 \times 10^{8} \mathrm{cfu} / \mathrm{kg}$, respectively). Most of the adverse effects observed were transient and related to physiological responses to infection and stress, rather than to the intrinsic toxicity of the bacterial treatment. The studies in pigs found no endotoxic or septic shock reactions. In tumor-bearing mice, VNP20009 accumulates preferentially in tumors over livers at a ratio of $1000: 1$, but also in dogs with spontaneous neoplasia tumor colonization was detectable in 10 out of 24 Salmonella-treated cases $(42 \%)$ (Thamm et al., 2005). Those promising features of preferential localization and apparent lack of toxicity allowed VNP20009 to enter clinical development in 1999.

In the first-in-man study performed by Vion Pharmaceuticals Inc., a total of 25 patients - 24 with metastatic melanoma and one with metastatic renal cancer - were treated with 30-minute intravenous bolus infusions of VNP20009 dose ranging from $10^{6}$ to $10^{9} \mathrm{cfu} / \mathrm{m}^{2}$. On the basis of dose-limiting toxicity symptoms, the MTD of VNP20009 in humans was estimated to be $3.0 \times 10^{8} \mathrm{cfu} /$ $\mathrm{m}^{2}$. Adverse reactions at higher doses included fever, hypotension, anemia and thrombocytopenia and were probably due to cytokine release. Despite VNP20009 attenuation, significant amounts of TNF were detected in the patients' peripheral blood. Most adverse effects were mild and rapidly reversible, but none of the $25 \mathrm{pa}-$ tients experienced objective cancer regression. Bacteria were rapidly cleared from the peripheral blood and tumor colonization by Salmonella could be detected only in three patients (Toso et al., 2002). This result was clearly in contrast with data from the murine tumor models.

In a subsequent clinical study, additional 4 patients with metastatic melanoma received a 4-hour intravenous infusion of VNP20009 at the MTD of $3.0 \times 10^{8} \mathrm{cfu} / \mathrm{m}^{2}$. Adverse effects of the treatment included fever, chills and nausea, but were minor and transient. VNP20009 was detectable in samples of patients' blood up to 2 hours post treatment. No Salmonella could be cultured from tumor biopsies taken within 2 weeks of therapy (Heimann \& Rosenberg, 2003).

The results of VNP20009 phase I clinical trials did not confirm Salmonella accumulation and tumor regression similar to previous preclinical data. However, the important finding is that VNP20009 can be safely ad- 
Table 4. Applications of S. Typhimurium as a vaccine vector

\begin{tabular}{|c|c|c|c|c|c|c|c|}
\hline Plasmid containing: & Promoter & $\begin{array}{l}\text { Salmonella } \\
\text { strain }\end{array}$ & Tumor & $\begin{array}{l}\text { Mouse } \\
\text { strain }\end{array}$ & Route* & $\mathrm{P} / \mathrm{T}^{* *}$ & References \\
\hline Beta-galactosidase ( $\beta$-gal) & CMV & SL7207 & $\begin{array}{l}\beta-g a l+-F 1 A 11 \\
\text { fibrosarcoma }\end{array}$ & Balb/c & $\mathrm{O}$ & $\mathrm{P}$ & (Paglia et al., 1998) \\
\hline $\begin{array}{l}\text { MG7-Ag-mimotope-PA- } \\
\text { DRE ( } T_{h} \text {-epitope) }\end{array}$ & CMV & SL3261 & $\begin{array}{l}\text { Ehrlich ascites } \\
\text { carcinoma }\end{array}$ & Balb/c & $\mathrm{O}$ & $\mathrm{P}$ & (Guo et al., 2003) \\
\hline $\begin{array}{l}\text { MG7-Ag-mimotope- } \\
\text { HBCAg }\end{array}$ & CMV & $X 4550$ & $\begin{array}{l}\text { Ehrlich ascites } \\
\text { carcinoma }\end{array}$ & Balb/c & $\mathrm{O}$ & $\mathrm{P}$ & (Meng et al., 2005) \\
\hline mAFP & CMV & Not stated & $\begin{array}{l}\text { CT26-mAFP } \\
\text { colon carcinoma } \\
\text { Hepa1-6 hepa- } \\
\text { toma }\end{array}$ & $\begin{array}{l}\text { Balb/C } \\
\text { C57J/L }\end{array}$ & 0 & $\mathrm{P}$ & (Chou et al., 2006) \\
\hline SopE-NY-ESO-1*** & Psop & $\Delta p h o P \Delta p h o Q$ & CMS5a sarcoma & Balb/c & $\begin{array}{l}\mathrm{O} \\
\mathrm{IT}\end{array}$ & $\mathrm{T}$ & (Nishikawa et al., 2006) \\
\hline $\begin{array}{l}\text { Tyrosine hydroxylase } \\
\text { epitopes-Ub }\end{array}$ & CMV & SL7207 & $\begin{array}{l}\text { NXS2 neurobla- } \\
\text { stoma }\end{array}$ & $\mathrm{A} / \mathrm{J}$ & $\mathrm{O}$ & $P+T$ & (Huebener et al., 2008) \\
\hline Survivin epitopes-Ub & CMV & SL7207 & $\begin{array}{l}\text { NXS2 neurobla- } \\
\text { stoma }\end{array}$ & $A / J$ & $\mathrm{O}$ & $P+T$ & (Fest et al., 2009) \\
\hline SopE-Hsp70-Trp2 & Psop & SL3261 & $\begin{array}{l}\text { B16F10 mela- } \\
\text { noma }\end{array}$ & C57BL/6J & $\mathrm{O}$ & $P+T$ & (Zhu et al., 2010) \\
\hline $\begin{array}{l}\text { SseF-CO-Survivin } \\
+ \text { STAT3shRNA }\end{array}$ & PsseA & MVP728 YS1646 & $\begin{array}{l}\text { B16F10 mela- } \\
\text { noma }\end{array}$ & C57BL/6 & $\mathrm{O}$ & $\mathrm{T}$ & (Manuel et al., 2011) \\
\hline mPSCA & CMV & SL7207 & $\begin{array}{l}\text { TRAMPC1 pro- } \\
\text { state carcinoma }\end{array}$ & C57BL/6 & $\mathrm{O}$ & $\mathrm{P}$ & (Ahmad et al., 2011) \\
\hline YopE-VEGFR2 & Plac & SB824 & $\begin{array}{l}\text { B16F10 mela- } \\
\text { noma }\end{array}$ & $\mathrm{C} 57 \mathrm{BI} / 6$ & OG & $\mathrm{P}$ & (Jellbauer et al., 2012) \\
\hline Endoglin & CMV & SL7207 & $\begin{array}{l}\text { B16F10 mela- } \\
\text { noma } \\
\text { Renca renal } \\
\text { carcinoma }\end{array}$ & $\begin{array}{l}\text { C57BI/6 } \\
\text { Balb/c }\end{array}$ & $\mathrm{O}$ & $P+T$ & (Jarosz et al., 2013) \\
\hline
\end{tabular}

${ }^{*} \mathrm{O}$, oral; OG, orogastric; IT, intratumoral; ${ }^{* *} \mathrm{P}$, prophylactic-, T, therapeutic approach; ${ }^{* *}$ underlined, Salmonella protein fragments serving as secretion signals; ${ }^{* * *} \mathrm{CO}$, codon optimized.

ministered to humans in large doses and that the toxicity of this bacterial strain is limited. Moreover, the first-inman study revealed that low tumor targeting in humans is a crucial therapeutic drawback of VNP20009. Since this feature can be significantly improved using genetic engineering, we made an attempt to enhance the accumulation of Salmonella in human tumors by constructing a VNP20009 strain expressing single chain antibody fragments specific to the carcinoembryonic antigen (CEA; Fig. 1). This VNP derivative was able to efficiently target CEA-expressing tumors in mice and could possibly overcome the targeting limitations of VNP20009 in humans, since CEA is present on more than $50 \%$ of human carcinomas (Bereta et al., 2007).

In summary, bacterial cancer therapy has recently moved beyond an interesting concept and has by now been supported by solid preclinical and clinical data. The unique features of bacterial therapeutics create the opportunity for novel anticancer strategies as bacteria meet all requirements for an ideal tumor-targeting agent. While the mechanism of action is often unclear, many examples have already proved that cancer treatment with bacteria can be site-specific, highly focused on the tumor and safe to other tissues. Among bacterial strains evaluated as cancer therapeutics so far, Salmonella Typhimurium is one of the most promising with first-in-man studies that support feasibility of clinical application. However, excellent tumor colonization observed in murine models was not confirmed in humans, suggesting that tumor targeting is the major obstacle for further development. As

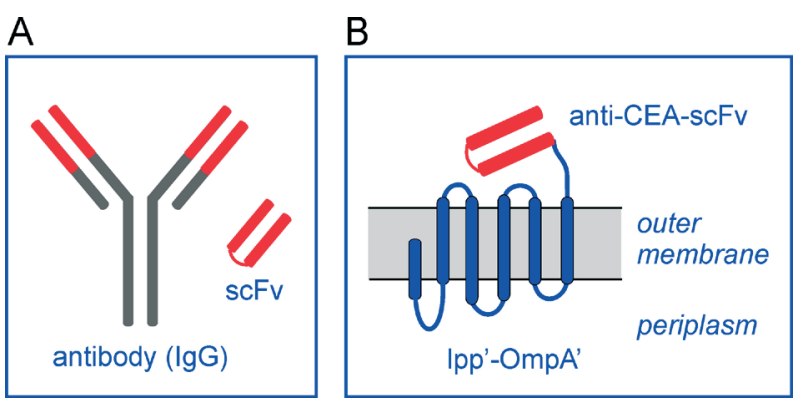

Figure 1. Tumor targeting of Salmonella via the anti-CEA antibody fragment.

(A) a single chain antibody fragment ( $\mathrm{s} \mathrm{CFv}$ ) specific to carcinoembryonic antigen (CEA) was derived from a CEA-specific immunoglobulin G molecule; (B) A DNA sequence encoding scFv was fused with the gene coding for OmpA, an outer membrane protein of E. coli, and expressed in VNP20009, an attenuated strain of Salmonella Typhimurium. 
many researchers focus on the effector molecules and other antitumor features of $S$. Typhimurium, insufficient localization in human tumors remains to be an unsolved issue. Targeting based on an antibody-fragment specific to TAAs is one of the few approaches proposed to overcome this drawback of therapeutic Salmonella strains.

\section{Acknowledgements}

The authors gratefully acknowledge financial support from the Polish National Centre for Research and Development through INNOTECH grant no. 152553 INNOTECH grant no. 152553 and the funding from the Jagiellonian University within the SET project cofinanced by the European Union.

\section{REFERENCES}

Ahmad S, Casey G, Cronin M, Rajendran S, Sweeney P, Tangney M, O'Sullivan GC (2011) Induction of effective antitumor response after mucosal bacterial vector mediated DNA vaccination with endogenous prostate cancer specific antigen. J Urol 186: 687-693.

Alexandroff AB, Jackson AM, O’Donnell MA, James, K (1999) BCG immunotherapy of bladder cancer: 20 years on. Lancet 353: 16891694.

Altieri DC (2003) Validating survivin as a cancer therapeutic target. Nat Rev Cancer 3: 46-54

Anderson DG, Kowalczykowski SC (1998) Reconstitution of an SOS response pathway: derepression of transcription in response to DNA breaks. Cell 95: 975-979.

Angelakopoulos H, Hohmann EL (2000) Pilot study of phoP/phoQdeleted Salmonella enterica serovar typhimurium expressing Helicobacter pylori urease in adult volunteers. Infect Immun 68: 2135-2141.

Avogadri F, Martinoli C, Petrovska L, Chiodoni C, Transidico P, Bronte V, Longhi R, Colombo MP, Dougan G, Rescigno M (2005) Cancer immunotherapy based on killing of Salmonella-infected tumor cells. Cancer Res 65: 3920-3927.

Bajaj V, Hwang C, Lee CA (1995) hilA is a novel ompR/toxR family member that activates the expression of Salmonella typhimurium invasion genes. Mol Microbiol 18: 715-727.

Baumler AJ, Tsolis RM, Ficht TA, Adams LG (1998) Evolution of host adaptation in Salmonella enterica. Infect Immun 66: 4579-4587.

Bereta M, Hayhurst A, Gajda M, Chorobik P, Targosz M, Marcinkiewicz J, Kaufman HL (2007) Improving tumor targeting and therapeutic potential of Salmonella VNP20009 by displaying cell surface CEA-specific antibodies. V accine 25: 4183-4192.

Bermudes D, Zheng LM, King IC (2002) Live bacteria as anticancer agents and tumor-selective protein delivery vectors. Curr Opin Drug Discov Devel 5: 194-199.

Blache CA, Manuel ER, Kaltcheva TI, Wong AN, Ellenhorn JD, Blazar BR, Diamond DJ (2012) Systemic delivery of Salmonella typhimurium transformed with IDO shRNA enhances intratumoral vector colonization and suppresses tumor growth. Cancer Res 72: 64476456.

Cao HD, Yang YX, Lu L, Liu SN, Wang PL, Tao XH, Wang LJ, Xiang TX (2010) Attenuated Salmonella typhimurium carrying TRAIL and VP3 genes inhibits the growth of gastric cancer cells in vitro and in vivo. Tumori 96: 296-303.

Chakravortty D, Hansen-Wester I, Hensel M (2002) Salmonella pathogenicity island 2 mediates protection of intracellular Salmonella from reactive nitrogen intermediates. J Exp Med 195: 1155-1166.

Chatfield SN, Charles IG, Makoff AJ, Oxer MD, Dougan G, Pickard D, Slater D, Fairweather NF (1992) Use of the nirB promoter to direct the stable expression of heterologous antigens in Salmonella oral vaccine strains: development of a single-dose oral tetanus vaccine. Biotechnology (NY) 10: 888-892.

Chen J, Yang B, Cheng X, Qiao Y, Tang B, Chen G, Wei J, Liu X, Cheng W, Du P, Huang X, Jiang W, Hu Q, Hu Y, Li J, Hua ZC (2012) Salmonella-mediated tumor-targeting TRAIL gene therapy significantly suppresses melanoma growth in mouse model. Cancer S $c i$ 103: $325-333$.

Chorobik P, Marcinkiewicz M (2011) Therapeutic vaccines based on genetically modified Salmonella: a novel strategy in cancer immunotherapy. Polskie Archiwum Medycyny Wewnętrznej 121: 461-466.

Chou CK, Hung JY, Liu JC, Chen CT, Hung MC (2006) An attenuated Salmonella oral DNA vaccine prevents the growth of hepatocellular carcinoma and colon cancer that express alpha-fetoprotein. Cancer Gene Ther 13: 746-752.

Dai MS, Nitcheu-Tefit J, Alcock S, Ramirez-Jimenez F, Chao TY, Baril P, Rocha M, Brett SJ, Stauss HJ, Vassaux G (2009) Development of an Escherichia coli expressing listeriolysin-O vaccine against Wilms tumor gene 1-expressing tumors. J Immunother 32: 845-855.
Dang LH, Bettegowda C, Huso DL, Kinzler KW, Vogelstein B (2001) Combination bacteriolytic therapy for the treatment of experimental tumors. Proc Natl Acad Sci USA 98: 15155-15160.

Deng Y, Lin Y, Wu X (2002) TRAIL-induced apoptosis requires Baxdependent mitochondrial release of Smac/DIABLO. Genes Dev 16: $33-45$.

Feasey NA, Dougan G, Kingsley RA, Heyderman RS, Gordon MA (2012) Invasive non-typhoidal Salmonella disease: an emerging and neglected tropical disease in Africa. Lancet 379: 2489-2499.

Fest S, Huebener N, Bleeke M, Durmus T, Stermann A, Woehler A, Baykan B, Zenclussen AC, Michalsky E, Jaeger IS, Preissner R, Hohn O, Weixler S, Gaedicke G, Lode HN (2009) Survivin minigene DNA vaccination is effective against neuroblastoma. Int J Cancer 125: $104-114$.

Forbes NS (2010) Engineering the perfect (bacterial) cancer therapy. Nat Rev Cancer 10: 785-794.

Fu W, Chu L, Han X, Liu X, Ren D (2008) Synergistic antitumoral effects of human telomerase reverse transcriptase-mediated dual-apoptosis-related gene vector delivered by orally attenuated Salmonella enterica Serovar Typhimurium in murine tumor models. J Gene Med 10: 690-701.

Fulda S, Wick W, Weller M, Debatin KM (2002) Smac agonists sensitize for Apo2L/TRAIL- or anticancer drug-induced apoptosis and induce regression of malignant glioma in vivo. Nat Med 8: 808-815.

Galan JE, Collmer A (1999) Type III secretion machines: bacterial devices for protein delivery into host cells. Science 284: 1322-1328.

Galmbacher K, Heisig M, Hotz C, Wischhusen J, Galmiche A, Bergmann B, Gentschev I, Goebel W, Rapp UR, Fensterle J (2010) Shigella mediated depletion of macrophages in a murine breast cancer model is associated with tumor regression. PLoS One 5: e9572.

Ganai S, Arenas RB, Forbes NS (2009) Tumour-targeted delivery of TRAIL using Salmonella typhimurium enhances breast cancer survival in mice. Br J Cancer 101: 1683-1691.

Garmory HS, Brown KA, Titball RW (2002) Salmonella vaccines for use in humans: present and future perspectives. FEMS Microbiol Rev 26: 339-353.

Green PN, Hoption Cann SA (2007) Bacterial anti-cancer vaccines: a science frozen in time. Microbiologist 8: 29-34.

Guibourdenche M, Roggentin P, Mikoleit M, Fields PI, Bockemuhl J, Grimont PA, Weill FX (2010) Supplement 2003-2007 (No 47) to the White-Kauffmann-Le Minor scheme. Res Microbiol 161: 26-29.

Guo CC, Ding J, Pan BR, Yu ZC, Han QL, Meng FP, Liu N, Fan DM (2003) Development of an oral DNA vaccine against MG7-Ag of gastric cancer using attenuated Salmonella typhimurium as carrier. World J Gastroenterol 9: 1191-1195.

Havashi K, Zhao M, Yamauchi K, Yamamoto N, Tsuchiva H, Tomita K, Hoffman RM (2009a) Cancer metastasis directly eradicated by targeted therapy with a modified Salmonella typhimurium. J Cell Biochem 106: 992-998.

Hayashi K, Zhao M, Yamauchi K, Yamamoto N, Tsuchiya H, Tomita K, Kishimoto H, Bouvet M, Hoffman RM (2009b) Systemic targeting of primary bone tumor and lung metastasis of high-grade osteosarcoma in nude mice with a tumor-selective strain of Salmonella typhimurium. Cell Cycle 8: 870-875.

Heimann DM, Rosenberg SA (2003) Continuous intravenous administration of live genetically modified Salmonella typhimurium in patients with metastatic melanoma. J Immunother 26: 179-180.

Hoiseth SK, Stocker BA (1985) Genes aroA and serC of Salmonella typhimurium constitute an operon. I Bacteriol 163: 355-361.

Hong EH, Chang SY, Lee BR, Pyun AR, Kim JW, Kweon MN, Ko HJ (2013) Intratumoral injection of attenuated Salmonella vaccine can induce tumor microenvironmental shift from immune suppressive to immunogenic. Vaccine 31: 1377-1384.

Huebener N, Fest S, Strandsby A, Michalsky E, Preissner R, Zeng Y, Gaedicke G, Lode HN (2008) A rationally designed tyrosine hydroxylase DNA vaccine induces specific antineuroblastoma immunity. Mol Cancer Ther 7: 2241-2251.

Hylander BL, Pitoniak R, Penetrante RB, Gibbs JF, Oktay D, Cheng J, Repasky EA (2005) The anti-tumor effect of Apo2L/TRAIL on patient pancreatic adenocarcinomas grown as xenografts in SCID mice. J Transl Med 3: 22.

Janssen R, van der Straaten T, van Diepen A, van Dissel JT (2003) Responses to reactive oxygen intermediates and virulence of Salmonella typhimurium. Microbes Infect 5: 527-534.

Jarosz M, Jazowiecka-Rakus J, Cichon T, Glowala-Kosinska M, Smolarczyk R, Smagur A, Malina S, Sochanik A, Szala S (2013) Therapeutic antitumor potential of endoglin-based DNA vaccine combined with immunomodulatory agents. Gene Ther 20: 262-273.

Jellbauer S, Panthel K, Hetrodt JH, Russmann H (2012) CD8 T-cell induction against vascular endothelial growth factor receptor 2 by Salmonella for vaccination purposes against a murine melanoma. PLoS One 7: e34214.

Jepson MA, Clark MA (2001) The role of M cells in Salmonella infection Microbes Infect 3: 1183-1190.

Jesenberger V, Procyk KJ, Yuan J, Reipert S, Baccarini M (2000) Salmonella-induced caspase-2 activation in macrophages: a novel 
mechanism in pathogen-mediated apoptosis. I Exp Med 192: 10351046.

Karbach J, Neumann A, Brand K, Wahle C, Siegel E, Maeurer M, Ritter E, Tsuji T, Gnjatic S, Old LJ, Ritter G, Jager E (2012) Phase I clinical trial of mixed bacterial vaccine (Coley's toxins) in patients with NY-ESO-1 expressing cancers: immunological effects and clinical activity. Clin Cancer Res 18: 5449-5459.

Kawai K, Miyazaki J, Joraku A, Nishiyama H, Akaza H (2013) Bacillus Calmette-Guerin (BCG) immunotherapy for bladder cancer: current understanding and perspectives on engineered BCG vaccine. Cancer Sci 104: 22-27.

Kim JM, Eckmann L, Savidge TC, Lowe DC, Witthoft T, Kagnoff MF (1998) Apoptosis of human intestinal epithelial cells after bacterial invasion. I Clin Invest 102: 1815-1823.

Kimura H, Zhang L, Zhao M, Hayashi K, Tsuchiya H, Tomita K, Bouvet M, Wessels J, Hoffman RM (2010) Targeted therapy of spinal cord glioma with a genetically modified Salmonella typhimurium. Cell Prolif 43: 41-48.

Knodler LA, Vallance BA, Celli J, Winfree S, Hansen B, Montero M, Steele-Mortimer O (2010) Dissemination of invasive Salmonella via bacterial-induced extrusion of mucosal epithelia. Proc Natl Acad Sci USA 107: 17733-17738.

Kolyva S, Waxin H, Popoff MY (1992) The Vi antigen of Salmonella typhi: molecular analysis of the viaB locus. J Gen Microbiol 138: 297-304.

LeBlanc HN, Ashkenazi A (2003) Apo2L/TRAIL and its death and decoy receptors. Cell Death Differ 10: 66-75.

Lee KC, Zheng L-M, Luo X, Clairmont C, Fischer J, Margitich D, Turnier J, Almassian B, Bermudes D, King I (2000) Comparative evaluation of the acute toxic effects in monkeys, pigs and mice of a genetically engineered Salmonella strain (VNP20009) being developed as an antitumor agent. Int I Toxicol 19: 19-25.

Loeffler M, Le’Negrate G, Krajewska M, Reed JC (2008) IL-18-producing Salmonella inhibit tumor growth. Cancer Gene Ther 15: 787-794.

Loeffler M, Le'Negrate G, Krajewska M, Reed JC (2009) Salmonella typhimurium engineered to produce CCL21 inhibit tumor growth. Cancer Immunol Immunother 58: 769-775.

Low KB, Ittensohn M, Luo X, Zheng LM, King I, Pawelek JM, Bermudes D (2004) Construction of VNP20009: a novel, genetically stable antibiotic-sensitive strain of tumor-targeting Salmonella for parenteral administration in humans. Methods Mol Med 90: 47-60.

Lucas RL, Lostroh CP, DiRusso CC, Spector MP, Wanner BL, Lee CA (2000) Multiple factors independently regulate hilA and invasion gene expression in Salmonella enterica serovar typhimurium. I Bacteriol 182: 1872-1882.

Malik-Kale P, Jolly CE, Lathrop S, Winfree S, Luterbach C, SteeleMortimer O (2011) Salmonella - at home in the host cell. Front Microbiol 2: 125.

Malik-Kale P, Winfree S, Steele-Mortimer O (2012) The bimodal lifestyle of intracellular Salmonella in epithelial cells: replication in the cytosol obscures defects in vacuolar replication. PLoS One 7: e38732.

Manuel ER, Blache CA, Paquette R, Kaltcheva TI, Ishizaki H, Ellenhorn JD, Hensel M, Metelitsa L, Diamond DJ (2011) Enhancement of cancer vaccine therapy by systemic delivery of a tumor-targeting Salmonella-based STAT3 shRNA suppresses the growth of established melanoma tumors. Cancer Res 71: 4183-4191.

Martinez-Argudo I, Jepson MA (2008) Salmonella translocates across an in vitro $M$ cell model independently of SPI-1 and SPI-2. Microbiology 154: 3887-3894.

McCarthy EF (2006) The toxins of William B Coley and the treatment of bone and soft-tissue sarcomas. Iowa Orthop J 26: 154-148.

McClelland M, Sanderson KE, Spieth J, Clifton SW, Latreille P, Courtney L, Porwollik S, Ali J, Dante M, Du F, Hou S, Layman D, Leonard S, Nguyen C, Scott K, Holmes A, Grewal N, Mulvaney E, Ryan E, Sun H, Florea L, Miller W, Stoneking T, Nhan M, Waterston R, Wilson RK (2001) Complete genome sequence of Salmonella enterica serovar Typhimurium LT2. Nature 413: 852-856.

Meng FP, Ding J, Yu ZC, Han QL, Guo CC, Liu N, Fan DM (2005) Oral attenuated Salmonella typhimurium vaccine against MG7-Ag mimotope of gastric cancer. World J Gastroenterol 11: 1833-1836.

Meng JZ, Dong YJ, Huang H, Li S, Zhong Y, Liu SL, Wang YD (2010) Oral vaccination with attenuated Salmonella enterica strains encoding T-cell epitopes from tumor antigen NY-ESO-1 induces specific cytotoxic T-lymphocyte responses. Clin V accine Immunol 17: 89-94.

Monack DM, Raupach B, Hromockyj AE, Falkow S (1996) Salmonella typhimurium invasion induces apoptosis in infected macrophages. Proc Natl Acad Sci USA 93: 9833-9838.

Nagakura C, Hayashi K, Zhao M, Yamauchi K, Yamamoto N, Tsuchiya H, Tomita K, Bouvet M, Hoffman RM (2009) Efficacy of a genetically-modified Salmonella typhimurium in an orthotopic human pancreatic cancer in nude mice. Anticancer Res 29: 1873-1878.

Niethammer AG, Lubenau H, Mikus G, Knebel P, Hohmann N, Leowardi C, Beckhove P, Akhisaroglu M, Ge Y, Springer M, Grenacher L, Buchler MW, Koch M, Weitz J, Haefeli WE, Schmitz-Winnenthal FH (2012) Double-blind, placebo-controlled first in human study to investigate an oral vaccine aimed to elicit an immune reaction against the VEGF-Receptor 2 in patients with stage IV and locally advanced pancreatic cancer. BMC Cancer 12: 361.

Nishikawa H, Sato E, Briones G, Chen LM, Matsuo M, Nagata Y, Ritter G, Jager E, Nomura H, Kondo S, Tawara I, Kato T, Shiku H, Old LJ, Galan JE, Gnjatic S (2006) In vivo antigen delivery by a Salmonella typhimurium type III secretion system for therapeutic cancer vaccines. I Clin Invest 116: 1946-1954.

Paglia P, Medina E, Arioli I, Guzman CA, Colombo MP (1998) Gene transfer in dendritic cells, induced by oral DNA vaccination with Salmonella typhimurium, results in protective immunity against a murine fibrosarcoma. Blood 92: 3172-3176.

Panthel K, Meinel KM, Domenech VE, Retzbach H, Igwe EI, Hardt, WD, Russmann H (2005) Salmonella pathogenicity island 2-mediated overexpression of chimeric $\mathrm{SspH} 2$ proteins for simultaneous induction of antigen-specific CD4 and CD8 T cells. Infect Immun 73: $334-341$.

Parry CM, Hien TT, Dougan G, White NJ, Farrar JJ (2002) Typhoid fever. $N$ Engl J Med 347: 1770-1782.

Paterson Y, Guirnalda PD, Wood LM (2010) Listeria and Salmonella bacterial vectors of tumor-associated antigens for cancer immunotherapy. Semin Immunol 22: 183-189.

Pawelek JM, Low KB, Bermudes D (1997) Tumor-targeted Salmonella as a novel anticancer vector. Cancer Res 57: 4537-4544.

Pei Z, Chu L, Zou W, Zhang Z, Qiu S, Qi R, Gu J, Qian C, Liu X (2004) An oncolytic adenoviral vector of Smac increases antitumor activity of TRAIL against HCC in human cells and in mice. Hepatology 39: 1371-1381.

Raupach B, Kaufmann S H (2001) Bacterial virulence, proinflammatory cytokines and host immunity: how to choose the appropriate Salmonella vaccine strain? Microbes Infect 3: 1261-1269.

Raupach B, Kurth N, Pfeffer K, Kaufmann SH (2003) Salmonella typhimurium strains carrying independent mutations display similar virulence phenotypes yet are controlled by distinct host defense mechanisms. I Immunol 170: 6133-6140.

Richardson MA, Ramirez T, Russell NC, Moye LA (1999) Coley toxins immunotherapy: a retrospective review. Altern Ther Health Med 5: $42-47$.

Saltzman DA, Heise CP, Hasz DE, Zebede M, Kelly SM, Curtiss R 3rd, Leonard AS, Anderson PM (1996) Attenuated Salmonella typhimurium containing interleukin-2 decreases MC-38 hepatic metastases: a novel anti-tumor agent Cancer Biother Radiopharm 11: 145-153.

Saunders NA, Simpson F, Thompson EW, Hill MM, Endo-Munoz L, Leggatt G, Minchin RF, Guminski A (2012) Role of intratumoural heterogeneity in cancer drug resistance: molecular and clinical perspectives. EMBO Mol Med 4: 675-684.

Schroeder N, Mota LJ, Meresse S (2011) Salmonella-induced tubular networks. Trends Microbiol 19: 268-277.

Shanker A, Brooks AD, Tristan CA, Wine JW, Elliott PJ, Yagita H, Takeda K, Smyth MJ, Murphy WJ, Sayers TJ (2008) Treating metastatic solid tumors with bortezomib and a tumor necrosis factorrelated apoptosis-inducing ligand receptor agonist antibody. J Natl Cancer Inst 100: 649-662.

Shwartzman G (1928) Studies on Bacillus typhosus toxic substances: I phenomenon of local skin reactivity to $B$ typhosus culture filtrate. J Exp Med 48: 247-68.

Shwartzman G (1935) Hemorrhagic necrosis and regression sarcoma 180. Science 82: 201.

Singh R, Wallecha A (2011) Cancer immunotherapy using recombinant Listeria monocytogenes: transition from bench to clinic. Hum Vaccin 7: 497-505.

Song J, Willinger T, Rongvaux A, Eynon EE, Stevens S, Manz MG, Flavell RA, Galan JE (2010) A mouse model for the human pathogen Salmonella typhi. Cell Host Microbe 8: 369-376.

St Jean AT, Zhang M, Forbes NS (2008) Bacterial therapies: completing the cancer treatment toolbox. Curr Opin Biotechnol 19: 511-517.

Steele-Mortimer O (2008) The Salmonella-containing vacuole: moving with the times. Curr Opin Microbiol 11: 38-45.

Steele-Mortimer O, Meresse S, Gorvel JP, Toh BH, Finlay BB (1999) Biogenesis of Salmonella typhimurium-containing vacuoles in epithelial cells involves interactions with the early endocytic pathway. Cell $\mathrm{Mi}$ crobiol 1: 33-49.

Stritzker J, Weibel S, Seubert C, Gotz A, Tresch A, van Rooijen N, Oelschlaeger TA, Hill PJ, Gentschev I, Szalay AA (2010) Enterobacterial tumor colonization in mice depends on bacterial metabolism and macrophages but is independent of chemotaxis and motility. Int J Med Microbiol 300: 449-56.

Strugnell R, Dougan G, Chatfield S, Charles I, Fairweather N, Tite J, Li JL, Beesley J, Roberts M (1992) Characterization of a Salmonella typhimurium aro vaccine strain expressing the P 69 antigen of Bordetella pertussis. Infect Immun 60: 3994-4002.

Swart AL, Hensel M (2012) Interactions of Salmonella enterica with dendritic cells. Virulence 3 (Epub ahead of print).

Tangney M, van Pijkeren JP, Gahan CG (2010) The use of Listeria monocytogenes as a DNA delivery vector for cancer gene therapy. Bioeng Bugs 1: 284-287. 
Thamm DH, Kurzman ID, King I, Li Z, Sznol M, Dubielzig RR, Vail DM, MacEwen EG (2005) Systemic administration of an attenuated, tumor-targeting Salmonella typhimurium to dogs with spontaneous neoplasia: phase I evaluation. Clin Cancer Res 11: 4827-4834.

Tindall BJ, Grimont PA, Garrity GM, Euzeby JP (2005) Nomenclature and taxonomy of the genus Salmonella. Int J Syst Evol Microbiol 55: 521-524.

Toley BJ, Forbes NS (2012) Motility is critical for effective distribution and accumulation of bacteria in tumor tissue. Integr Biol (Camb) 4 : 165-176.

Tome Y, Zhang Y, Momiyama M, Maehara H, Kanaya F, Tomita K, Tsuchiya H, Bouvet M, Hoffman RM, Zhao M (2013) Primer dosing of $S$. typhimurium A1-R potentiates tumor-targeting and efficacy in immunocompetent mice. Anticancer Res 33: 97-102.

Toso JF, Gill VJ, Hwu P, Marincola FM, Restifo NP, Schwartzentruber DJ, Sherry RM, Topalian SL, Yang JC, Stock F, Freezer LJ, Morton KE, Seipp C, Haworth L, Mavroukakis S, White D, MacDonald S, Mao J, Sznol M, Rosenberg SA (2002) Phase I study of the intravenous administration of attenuated Salmonella typhimurium to patients with metastatic melanoma. J Clin Oncol 20: 142-152.

Tran J, Rak J, Sheehan C, Saibil SD, LaCasse E, Korneluk RG, Kerbel RS (1999) Marked induction of the IAP family antiapoptotic proteins survivin and XIAP by VEGF in vascular endothelial cells. Biochem Biophys Res Commun 264: 781-788.

Umer B, Good D, Anne J, Duan W, Wei MQ (2012) Clostridial spores for cancer therapy: targeting solid tumour microenvironment. $J$ Toxicol 2012: 862764 .

Velge P, Wiedemann A, Rosselin M, Abed N, Boumart Z, Chausse AM, Grepinet O, Namdari F, Roche SM, Rossignol A, VirlogeuxPayant I (2012) Multiplicity of Salmonella entry mechanisms, a new paradigm for Salmonella pathogenesis. Microbiologyopen 1: 243-258.

Vendrell A, Gravisaco MJ, Pasetti MF, Croci M, Colombo L, Rodriguez C, Mongini C, Waldner CI (2011) A novel Salmonella Typhibased immunotherapy promotes tumor killing via an antitumor Th1type cellular immune response and neutrophil activation in a mouse model of breast cancer. Vaccine 29: 728-736.

Walczak H, Miller RE, Ariail K, Gliniak B, Griffith TS, Kubin M, Chin W, Jones J, Woodward A, Le T, Smith C, Smolak P, Goodwin RG, Rauch CT, Schuh JC, Lynch DH (1999) Tumoricidal activity of tumor necrosis factor-related apoptosis-inducing ligand in vivo. Nat Med 5: 157-163.

Xiang R, Primus FJ, Ruehlmann JM, Niethammer AG, Silletti S, Lode HN, Dolman CS, Gillies SD, Reisfeld RA (2001) A dual-function DNA vaccine encoding carcinoembryonic antigen and CD40 ligand trimer induces $\mathrm{T}$ cell-mediated protective immunity against colon cancer in carcinoembryonic antigen-transgenic mice. J Immunol 167: 4560-4565.

Xiong G, Husseiny MI, Song L, Erdreich-Epstein A, Shackleford GM, Seeger RC, Jackel D, Hensel M, Metelitsa LS (2010) Novel cancer vaccine based on genes of Salmonella pathogenicity island 2. Int J Cancer 126: 2622-2634.

Yagita, H, Takeda, K, Hayakawa, Y, Smyth, M J, Okumura, K (2004) TRAIL and its receptors as targets for cancer therapy. Cancer Sci 95: $777-783$.

Yoon WS, Chae YS, Hong J, Park YK (2011) Antitumor therapeutic effects of a genetically engineered Salmonella typhimurium harboring TNF-alpha in mice. Appl Microbiol Biotechnol 89: 1807-1819.

Yrlid U, Wick MJ (2000) Salmonella-induced apoptosis of infected macrophages results in presentation of a bacteria-encoded antigen after uptake by bystander dendritic cells. I Exp Med 191: 613-624.

Yu B, Yang M, Shi L, Yao Y, Jiang Q, Li X, Tang LH, Zheng B J, Yuen KY, Smith DK, Song E, Huang JD (2012) Explicit hypoxia targeting with tumor suppression by creating an "obligate" anaerobic Salmonella Typhimurium strain. Sci Rep 2: 436.

Zhang XD, Zhang XY, Gray CP, Nguyen T, Hersey P (2001) Tumor necrosis factor-related apoptosis-inducing ligand-induced apoptosis of human melanoma is regulated by smac/DIABLO release from mitochondria. Cancer Res 61: 7339-7348.

Zhang Y, Tome Y, Suetsugu A, Zhang L, Zhang N, Hoffman RM, Zhao M (2012a) Determination of the optimal route of administration of Salmonella typhimurium A1-R to target breast cancer in nude mice. Anticancer Res 32: 501-508.

Zhang Y, Xia L, Zhang X, Ding X, Yan F, Wu F (2012b) Escherichia coli Nissle 1917 targets and restrains mouse B16 melanoma and 4T1 breast tumors through expression of azurin protein. Appl Environ Microbiol 78: 7603-7610.

Zhao M, Geller J, Ma H, Yang M, Penman S, Hoffman RM (2007) Monotherapy with a tumor-targeting mutant of Salmonella typhimurium cures orthotopic metastatic mouse models of human prostate cancer. Proc Natl Acad Sci USA 104: 10170-10174.

Zhao M, Yang M, Li XM, Jiang P, Baranov E, Li S, Xu M, Penman S, Hoffman RM (2005) Tumor-targeting bacterial therapy with amino acid auxotrophs of GFP-expressing Salmonella typhimurium. Proc Natl Acad Sci USA 102: 755-760.

Zhao M, Yang M, Ma H, Li X, Tan X, Li S, Yang Z, Hoffman RM (2006) Targeted therapy with a Salmonella typhimurium leucine-arginine auxotroph cures orthotopic human breast tumors in nude mice. Cancer Res 66: 7647-7652.

Zhu X, Zhou P, Cai J, Yang G, Liang S, Ren D (2010) Tumor antigen delivered by Salmonella III secretion protein fused with heat shock protein 70 induces protection and eradication against murine melanoma. Cancer Sci 101: 2621-2628.

Zhuang SM, Shvarts A, van Ormondt H, Jochemsen AG, van der Eb AJ, Noteborn MH (1995) Apoptin, a protein derived from chicken anemia virus, induces p53-independent apoptosis in human osteosarcoma cells. Cancer Res 55: 486-489. 